their accustomed place of worship, are invited to send their contributions direct to me at the Mansion House.

I am, Sirs, your obedient servant,

Joseph C. DIMSDALE, Lord Mayor.

The Mansion House, London, E.C., June 11th, 1902.

\section{PAYING WARDS AND PAYING HOSPITALS.}

\section{To the Editors of THE LANCET.}

SIRS, - Will you kindly lend me a little of your valuable space to congratulate Dr. R. Saundby and Mr. B. W. Housman on their excellent letters in THE LANCET of May 10th, p. 1356. They show, in both cases, a proper grasp of the situation and they proceed on lines of real reform in the best interests of all classes of medical practitioners. Our profession, like all other professions, must live; and, as society is now constituted, it ought to be paid for its labours on a proper financial basis. The time is past for medical men to lay the burthen of paying for the poor entirely upon the rich. With civilisation advancing and wages increasing money has become the universal medium of exchange. Each class is getting more and more independent of other classes and must stand on its own feet in the different relations of life, and so it has come about that charity to the working class is unnecessary and uncalled for, and the doctor has to manage his professional work as all other professions have to manage theirs, on true business lines all round. The ideal state of matters, then, would be that we medical men should be paid on a fitting scale for every form of work done, whether in a hospital or club, or any other quasi-benevolent institution, and that the charitable element, so far as our duties are concerned, should be entirely eliminated. I need scarcely add that practically such a dream cannot be realised per saltum. So complete a change in our relations with the public must, we know, take a long time to effect. Above all, we ourselves must learn to combine. Looking at matters not only as they affect us, but as they react on the public at large, if time and your space were available it could be clearly shown that such a reform would encourage on the part of our people the best of all qualities in the wear and tear of ife-good, honest independence. It is because there is so much of this spirit in the letters I have referred to that I welcome them as I do.

Dr. Saundby, having scored a victory over the ill-considered and impracticable, if well-intentioned, scheme of the Birmingham Consultative Institute, has shown much good sence and magnanimity in recognising what was really valuable and sure ultimately to emerge from that conception. He very properly argues for taking time by the forelock and invites the opinions of others on the principles which should regulate a self-supporting scheme of paying hospitals open to the better-paid working man and to lower middle-class patients.

Having bestowed some time and attention on the conisideration of this subject I venture to suggest certain propositions-not by any means as if I considered them as proved to the satisfaction of everybody but as the basis of further discussion of the subject. The first proposition I would venture to advance is that the scheme should be worked on coöperative principles on both sides. Every person, without distinction as to wages, salary, or otherwise, should be able if he chose to avail himself of such an institution and every regular consultant, medical, surgical, or specialist, should be, if he or she chose, on the list of the recognised staff. Secondly, board, lodging, and nursing should be fixed at a moderate rate, while the fee for medical and surgical attendance should be left to the particular physician or surgeon in attendance. Thirdly, a list of physicians, surgeons, and specialists, with their fees, should be posted up in the hospital, patients being at liberty to select their own doctor. Consultations would be arranged for on similar lines.

In order to start such a hospital sufficient funds would require to be guaranteed. After a time the institution would have to be self-supporting. The friends of the working men and the working men themselves would have to be convinced of the wisdom of the scheme and agree heartily to help it in every way so as to make it successful. As to management a joint board of management should be formed, of which the medical element would have to constitute a full half and the representatives of the classes to be benefited the other half. The bargain must be a fair one between those who are giving their services and those who are accepting the same, both parties meeting on equal terms. The establishment would be run on strictly business lines. One objection to the scheme suggested which occurs to me is that there might be a press of cases waiting to be admitted and consequent grumbling on the part of those members of the staff who failed to get their patients into the hospital. The remedy would naturally be the provision of more beds and the hospital might be originally built on a plan which would readily admit of extension, and there would be no reason why another hospital might not be set up if the first one became, so to speak, too successful.

It will be seen that I have said nothing as to limiting those admitted so as to exclude the rich. I do not believe in any such tests. They are too inquisitorial and invidious to work well. But I would be in favour of getting as many as possible subscribers of $6 d$. weekly with a preferential right to admission and that on a reduced scale. This plan of itself would naturally limit the class of applicants and if the contributors were numerous would provide for a more certain and steady income at all times and seasons than if the scheme depended merely on the number of beds occupied.

One word in conclusion in favour of paying hospitals. As things are constituted at present patients with only moderate means must choose between expensive nursing homes and large fees and hospitals with no charge of any kind. Who can doubt that most prefer the latter alternative, and in this way the profession as a body (and I should think more particularly operating surgeons) lose very heavily? Surely, here the middle course is best and I believe that a via media will most easily be found by adopting some such plan as I have attempted all too ineffectively to sketch. I have left myself no room to deal with Mr. Housman's suggestions. But I hope, with your leave, to take them up by-and-by. I believe the principles I have tried to enunciate would equally well apply to clubs and club doctors.

May 27th, 1902 I am, Sirs, yours faithfully,

\section{ON THE USE OF THE TERM "BLASTOMA."}

\section{To the Editors of THE LANCET.}

SIRS, - In THE LANCext of May 31st (p. 1562) there is a letter from Professor Adami criticising my use of the term "blastoma." I must confess that I was not aware of the fact that the term had been used by Professor Klebs and I must thank Professor Adami for calling my attention to it. Since reading his letter I have referred to Klebs's work ("Allgemeine Pathologie") and I find that Professor Adami's description of Klebs's classification is not quite accurate. Klebs uses the term "blastomata" as a synonym for "true tumours," but he includes under this term many conditions which are not considered tumours at the present day. $\mathrm{He}$ divides the blastomata or true tumours into three primary classes. The first class he calls "typical blastomata" and uses the synonym "giant growths" (riesennuchs). They are those conditions which I called progressive hypertrophy. The second class is that of the "atypical blastomata" and includes all the ordinary tumours and also tubercle, leprosy, \&c. The third primary class is that of the "teratoblastomata" or "teratomata" which, besides dermoid cysts, \&c., includes tumours arising from foetal remains, such as those originating in branchial clefts, \&c. Thus the term "blastoma," as used by Klebs, includes all tumours, progressive hypertrophies, and tubercle, leprosy, \&c. I think that no one at the present day would defend this use of the term.

Professor Adami uses the term to designate the ordinary tumours as opposed to the teratomata-a use different to that of Klebs. Professor Adami's classification 1 is one rather of the antecedents of tumonr formation than of tumours themselves. As a classification of tumours it is nseless owing to the overlapping of the different subdivisions. Carcinoma, for instance, would occur in all the subdivisions of his group "blastomata." He draws too sharp and artificial a line between the teratomata and other tumours. He defines the blastomata as "tumours composed of the products of aberrant growth of cells and tissues of the individual in whom they develop," and the teratomata as "tumours composed of the products of growth of one individual within the

1 The Causation of Cancerous and other New Grow ths, Brit. Med. Jour., 1901, vol. i., March, 16th. 